\title{
Effect of Lime on the Index Properties of Black Cotton Soil and Mine tailings mixtures
}

\author{
H.N.Ramesh ${ }^{1}$, A.J.Krishnaiah ${ }^{2}$ and S.Shilpa shet ${ }^{3}$ \\ ${ }^{1}$ (Professor, Department of Civil Engineering, UVCE, Bangalore University, Bangalore-560056, India) \\ ${ }^{2}$ (Research scholar, Dept. of Civil Engineering, UVCE, Bangalore University, Bangalore-560056, India) \\ ${ }^{3}$ (Former P.G Student, Department of Civil Engineering, UVCE, Bangalore University, Bangalore-56, India)
}

\begin{abstract}
Index properties are extensively used in geotechnical engineering practice. Among them, liquid limit is an important physical property used in classification and correlations with engineering properties of soils. Liquid limit, plastic limit and shrinkage limit of Black cotton soil (BCS) and mine tailings (MT) mixtures treated with lime are investigated and are presented in this paper. In the present investigation an attempt has been made to utilize the mine tailings in geotechnical applications and to evaluate the index properties of black cotton soil and mine tailings mixture treated with lime. The test results indicate that the progressive decrease in liquid limit, decrease in plastic limit and increase in shrinkage limit with curing time. The liquid limit in particular is used in many correlations with engineering properties and it is significant to know the stress history and general properties of the soil met with constructions. Liquid limit is used for the estimation of compression index and compression index is useful for the settlement analysis of soils. The Physico-chemical mechanism which alter the index properties of black cotton soil and mine tailings mixture treated with lime and the mechanisms have been explained based on thickness of diffused double layer and alteration of the reaction products of soil-lime reaction .for various curing periods.
\end{abstract}

Keywords: Mine tailings, Curing period, diffused double layer, particle aggregation, cation exchange.

\section{INTRODUCTION}

The engineering behaviour of fine-grained soils depends on their water content. Liquid limit $\left(\mathrm{W}_{\mathrm{L}}\right)$ and plastic limit $\left(\mathrm{W}_{\mathrm{P}}\right)$ are important water contents as well as two important parameters of plasticity index $\left(\mathrm{P}_{\mathrm{I}}\right)$, which is the main index parameter of the classification of fine-grained soils. Plasticity index has also been used in correlation with many other engineering properties like internal friction angle, undrained shear strength, lateral earth pressure over consolidation ratio etc. Shrinkage limit $\left(\mathrm{S}_{\mathrm{L}}\right)$ is also an important parameter in which soils tend to shrink when they loose moisture. In particular, fine grained soils are susceptible to shrinkage and the resulting volume change. Shrinkage can cause cracking of soils that can adversely influence the behaviour of the soils. It is widely accepted that the liquid limit test is essentially a measure of the shear strength of soil that is so soft it approaches the liquid stage (Sowers et al 1959) [1]. Generally the plasticity, workability and strength properties of fine grained soils are improved by the addition of small quantities of lime (Bell, 1988a and 1988b, Diamond and Kinter, 1965) [2][3][4]. Most of the soils decreases the plasticity index by addition of lime and thereby increasing the workability (Thompson 1966)[5]. When liquid limit increases with lime addition, the plasticity index usually decreases because of the increase in the plastic limit. Mine tailings is the by-product obtained from mining industries and finely ground material which is discharged in to tailings impoundments after the extraction of minerals from underground mined ores. As a result of the crushing and grinding (milling) process, the large quantity of tailing particles are disposed in the form of slurry in to the tailings impoundments and later in the form of dumping which creates environmental problems. Mine tailings can be effectively utilized for civil engineering constructions which will minimize the disposal problems and reduce the environmental hazards (Pebble Project, 2005) [6]. Lime is an additive which has been recognized to bring several beneficial changes in the engineering properties of fine grained soils. Treatment with lime is observed to decrease the plasticity and shrink-swell potential and improve the strength characteristics of the soil (Sridharan et al 1986, Katti et al 1966) [7],[8]. According to Worth (1979) [9], a sustainable part of strength variation at the liquid limit obtained by using the Casagrande apparatus can be attributed to the fact that soil deformation in it is self weight-induced. Addition of lime or any other salts which decreases the thickness of diffused double layer because of increased valency of the exchangeable ion or in the increase in the electrolyte concentration (Sridharan and Jayadeva 1982) [10]. Udayashankar and Puranik (2012)[11], investigated the effect of Dandily fly ash treatment to the black cotton soils of Hubbali-Dharwad on their index properties in an effort to improve the geotechnical characteristics and it was observed that the liquid limit and plastic limits decrease while the shrinkage limit increases with the addition of fly ash. In the similar way, mine tailings can be used for the assessment of index properties of black cotton soil in presence of lime. 


\section{MATERIALS AND METHODS}

\subsection{Materials}

\subsubsection{Black Cotton Sol}

In the present investigation the black cotton soil was obtained from Davanagere, Karnataka state, India. This is a residual soil and was collected from an open excavation, at a depth of two meter below the natural ground surface. The black cotton soil was air dried, pulverized and passed through 425micron BIS sieve was used for the present investigation.

\subsubsection{Mine tailings}

Mine tailings was collected from an open dump from Kolar Gold Fields (KGF), Kolar, Karnataka, India. After removing the vegetations from the mine tailings, it was air dried, pulverized and passing through 425 micron BIS sieve was used in the present investigation.

\subsubsection{Lime}

Lime used in the present investigation was obtained from Fisher Scientific Chemicals private limited, Mumbai, India.

The physical properties of black cotton soil and mine tailings are presented in Table 1 and the chemical analysis of black cotton soil and mine tailings were carried out by adopting the standard procedures by P.R.Hesse, Soil Chemical Analysis published by Chemical Pub. Co. (1972) [12]. University of Michigan, and are presented in Table 2 and 3 respectively.

Table 1. Physical properties of Black Cotton Soil and Mine tailings (Ramesh et al 2012) [13].

\begin{tabular}{|l|c|c|}
\hline \multirow{2}{*}{ Properties } & \multicolumn{2}{c|}{ Values } \\
\cline { 2 - 3 } & BCS & MT \\
\hline Colour & Black & Pale gray \\
\hline Specific Gravity & 2.70 & 2.78 \\
\hline Liquid limit (\%) & 82.0 & 34.0 \\
\hline Plastic limit (\%) & 47.2 & Non plastic \\
\hline Plasticity Index (\%) & 34.8 & Non plastic \\
\hline Shrinkage limit (\%) & 8.4 & 24.6 \\
\hline Fine sand fraction (\%) & 10.0 & 17.0 \\
\hline Silt fraction (\%) & 21.2 & 70.4 \\
\hline Clay fraction (\%) & 68.8 & 12.6 \\
\hline Maximum dry density $\left(\mathrm{kN} / \mathrm{m}^{3}\right)$ & 14.3 & 15.7 \\
\hline Optimum moisture content (\%) & 29.9 & 21.54 \\
\hline
\end{tabular}

Table 2. Chemical properties of Black Cotton Soil.

\begin{tabular}{|l|c|}
\hline \multicolumn{1}{|c|}{ Chemical composition } & Percentage \\
\hline Silicon dioxide & 52.85 \\
\hline Alumina & 12.24 \\
\hline Iron oxide & 8.04 \\
\hline Titanium dioxide & 0.24 \\
\hline Calcium oxide & 6.01 \\
\hline Magnesium oxide & 2.94 \\
\hline Potassium oxide & 0.48 \\
\hline Loss on ignition & 16.18 \\
\hline Sodium oxide & 0.26 \\
\hline
\end{tabular}

Table 3. Chemical properties of Mine tailings.

\begin{tabular}{|c|c|c|c|c|c|c|c|c|c|c|c|c|c|}
\hline $\begin{array}{c}\text { Mater } \\
\text { ial }\end{array}$ & $\mathrm{PH}^{\mathrm{S}}$ & $\begin{array}{c}\mathrm{SiO}_{2} \\
(\%)\end{array}$ & $\begin{array}{c}\mathrm{Al}_{2} \mathrm{O} \\
4(\%)\end{array}$ & $\begin{array}{c}\mathrm{P}_{2} \mathrm{O}_{5} \\
(\%)\end{array}$ & $\begin{array}{c}\mathrm{K}_{2} \mathrm{O} \\
4(\%)\end{array}$ & $\begin{array}{c}\mathrm{Cu} \\
(\%)\end{array}$ & $\begin{array}{c}\mathrm{Pb} \\
(\%)\end{array}$ & $\begin{array}{c}\mathrm{As} \\
(\%)\end{array}$ & $\begin{array}{c}\mathrm{CN}^{-} \\
(\%)\end{array}$ & $\begin{array}{c}\mathrm{SO}_{3} \\
(\%)\end{array}$ & $\begin{array}{c}\mathrm{SO}_{4} \\
(\%)\end{array}$ & $\begin{array}{c}\mathrm{CaO} \\
(\%)\end{array}$ & $\begin{array}{c}\mathrm{MgO}^{(\%)} \\
(\%)\end{array}$ \\
\hline $\mathrm{MT}$ & 8.44 & 40.5 & 0.5 & 0.09 & 16.1 & $\begin{array}{c}2.55 \\
\mathrm{ppm}\end{array}$ & 0.04 & $\begin{array}{c}< \\
0.01\end{array}$ & $\mathrm{Nil}$ & 0.05 & 0.5 & 14.96 & 6.97 \\
\hline
\end{tabular}

\subsection{Methods adopted:}

2.2.1. Liquid limit: The liquid limit was conducted by using cone penetration method as per BIS: 2720 (Part V)-1985[14]. The liquid limit tests were carried out to secure a minimum of five points for plotting the flow curve. 
2.2.2. Plastic limit: The plastic limit was conducted as per BIS: 2720 (Part VI) - 1985[15].The plastic limit reported as an average of two determinations.

2.2.3. Shrinkage limit: The shrinkage limit was conducted as per BIS: 2720 (Part VI)-1972[16]. The shrinkage limit reported as an average of three determinations

\section{RESULTS AND DISCUSSIONS}

Liquid limit, plastic limit and shrinkage limit tests are carried out on black cotton soil and mine tailings respectively. Further, same tests were also carried out on black cotton soil and mine tailings mixtures treated with lime. 30\% of mine tailings for black cotton soil was found to be optimum percentage (Ramesh et al 2012) [13], and 3\% of lime for black cotton soil and mine tailings mixture was found to be optimum lime content (Ramesh et al 2013) [17]. The tests were conducted for 0, 7, 14 and 30 days curing periods and the results are presented.

\subsection{Effect of lime on the Liquid limit of black cotton soil and mine tailings mixture}

The liquid limit of black cotton soil and mine tailing are found to be $82 \%$ and $34 \%$ respectively. Addition of various percentages of mine tailings to black cotton soil, liquid limit decreases for immediate testing due to reduction in the specific surface area of the soil, the consequent decrease in the diffuse double layer thickness possibly accounts for the lower liquid limit of the treated soil during initial stages. Addition of mine tailings, decreases the liquid limit of black cotton soil and mine tailings mixture immediately due to replacement of exchangeable ions particularly monovalent ions by calcium ions and decrease the thickness of the diffused double layer leading to decrease in the water holding capacity (Sherwood 1958, Taylor et al 1960)[18],[19]. Liquid limit of black cotton soil and mine tailings mixture treated with lime is $61.3 \%$ on immediate testing and it was observed that liquid limit increases with increase in curing period to $71.92 \%$ for 30 days of curing as shown in Fig.1 and Table4.

Table 4. Liquid limit of black cotton soil treated with d percentages of mine tailings and lime for

\begin{tabular}{|c|c|c|c|c|}
\hline \multirow{3}{*}{ Mixtures } & \multicolumn{4}{|c|}{ Liquid Limit (\%) } \\
\hline & \multicolumn{4}{|c|}{ Curing period in days } \\
\hline & 0 & 7 & 14 & 30 \\
\hline BCS Alone & 82 & 82 & 82 & 82 \\
\hline MT Alone & 34 & 35.1 & 35.7 & 35.5 \\
\hline $\mathrm{BCS}+10 \% \mathrm{MT}$ & 60.8 & 67.5 & 70.2 & 69.4 \\
\hline $\mathrm{BCS}+20 \% \mathrm{MT}$ & 59.2 & 65.2 & 68.4 & 65.1 \\
\hline $\mathrm{BCS}+30 \% \mathrm{MT}$ & 57.9 & 61.1 & 65.7 & 62.7 \\
\hline $\mathrm{BCS}+40 \% \mathrm{MT}$ & 54.5 & 57.9 & 59.8 & 56.3 \\
\hline $\mathrm{BCS}+50 \% \mathrm{MT}$ & 48.4 & 52.3 & 55.3 & 54.9 \\
\hline $\mathrm{BCS}+60 \% \mathrm{MT}$ & 43.7 & 47.6 & 50.2 & 48.2 \\
\hline $\mathrm{BCS}+70 \% \mathrm{MT}$ & 40.2 & 39.7 & 42.1 & 42.3 \\
\hline $\mathrm{BCS}+80 \% \mathrm{MT}$ & 36.7 & 35.6 & 35.2 & 34.9 \\
\hline $\mathrm{BCS}+90 \% \mathrm{MT}$ & 34.2 & 34 & 35.3 & 35.8 \\
\hline $\mathrm{BCS}+30 \% \mathrm{MT}+3 \% \mathrm{~L}$ ime & 61.3 & 69.5 & 70 & 71.9 \\
\hline
\end{tabular}

Addition of lime initially leads to a decrease in liquid limit of black cotton soil and mine tailings mixture compare to untreated black cotton soil. This is due to depression in the diffused double layer thickness associated with the clay particles. Subsequent curing with lime addition leads to an increase in the liquid limit of the soil this is due to prolonged equilibrium of the lime-soil-mine tailings mixture results in formation of coarser aggregates and a more flocculated particle arrangement. Possibly, the water entrapped in the large void spaces of the flocculated structure of the soil fabric, thereby increase in liquid limit (prakash et al 1989) [20].

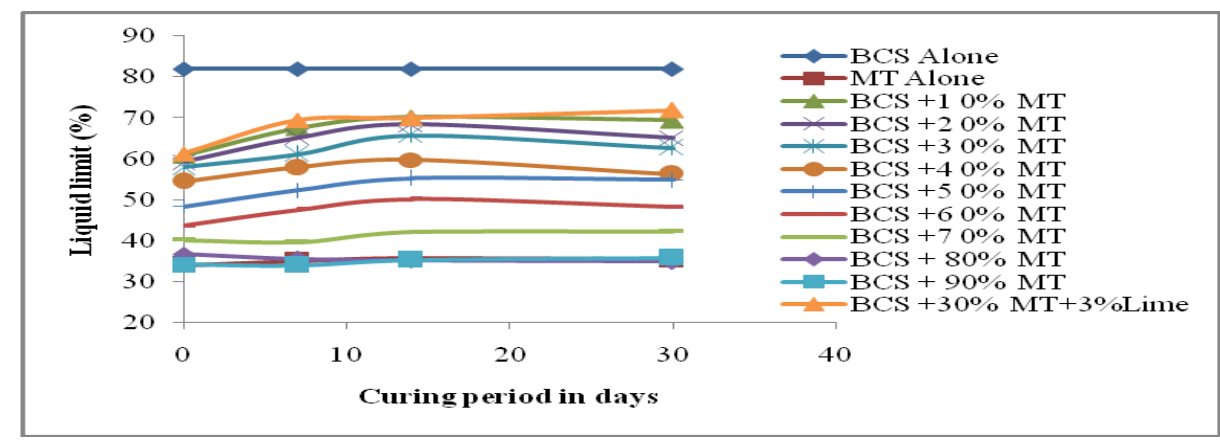

Fig. 1 Variation of liquid limit of black cotton soil treated with various percentages of mine tailings and lime for different curing periods 


\subsection{Effect of lime on the plastic limit of black cotton soil and mine tailings mixture}

The plastic limit of black cotton soil is found to be $47.2 \%$ and mine tailings is non plastic in nature. Addition of various percentages of mine tailings to black cotton soil, the plastic limit decreased immediately after the addition of mine tailings to black cotton soil and increases continuously with increase in curing period. The increase in plastic limit is due to decrease in diffused double layer thicken of clay particles leads to increase in shearing resistance, the soil fabric varies with changes in exchangeable cation and mine tailings concentration. Depending upon the particles arrangement size and shape of the pores vary. Thus the flocculated structure will have higher plastic limit (Sivapullaiah et al 1995) [21]. Immediately on addition of optimum 3\% lime, the plastic limit of black cotton soil and mine tailings mixture increases from $25.8 \%$ to $36.6 \%$. After curing for 30 days with 3\% lime, the plastic limit further increases to about $422 \%$ as shown in Fig 2 and Table 5.

Table 5. Plastic limit of black cotton soil treated with various percentages of mine tailings and lime for different curing periods

\begin{tabular}{|l|c|c|c|c|}
\hline \multirow{2}{*}{\multicolumn{1}{|c|}{ Mixtures }} & \multicolumn{4}{|c|}{ Plastic Limit (\%) } \\
\cline { 2 - 5 } & \multicolumn{4}{|c|}{ Curing period in days } \\
\cline { 2 - 5 } & 0 & 7 & 14 & 30 \\
\hline BCS Alone & 47.2 & 47.2 & 47.2 & 47.2 \\
\hline MT Alone & Non plastic & Non plastic & Non plastic & Non plastic \\
\hline BCS +1 0\% MT & 38.6 & 39.2 & 39.4 & 39.6 \\
\hline BCS +2 0\% MT & 31 & 31.4 & 32.1 & 32.8 \\
\hline BCS +3 0\% MT & 25.8 & 26.1 & 29.4 & 31 \\
\hline BCS +4 0\% MT & 23.2 & 23.6 & 24.1 & 24.9 \\
\hline BCS +5 0\% MT & 20.2 & 20.5 & 21.4 & 21.8 \\
\hline BCS +6 0\% MT & 19.3 & 19.8 & 20 & 21 \\
\hline BCS +7 0\% MT & 18.2 & 18.5 & 18.7 & 19 \\
\hline BCS + 80\% MT & 16.2 & 16.5 & 16.8 & 17.2 \\
\hline BCS + 90\% MT & Non plastic & Non plastic & Non plastic & Non plastic \\
\hline BCS +30\% MT+3\%Lime & 36.6 & 41.6 & 41.9 & 42.2 \\
\hline
\end{tabular}

The initial increase is due to decrease in the diffused double layer thickness of clay particles leads to increase in the shearing resistance at particles level and also flocculation of clay particles which leads to increased plastic limit with curing period (Sivapullaiah et al 1995)[21].

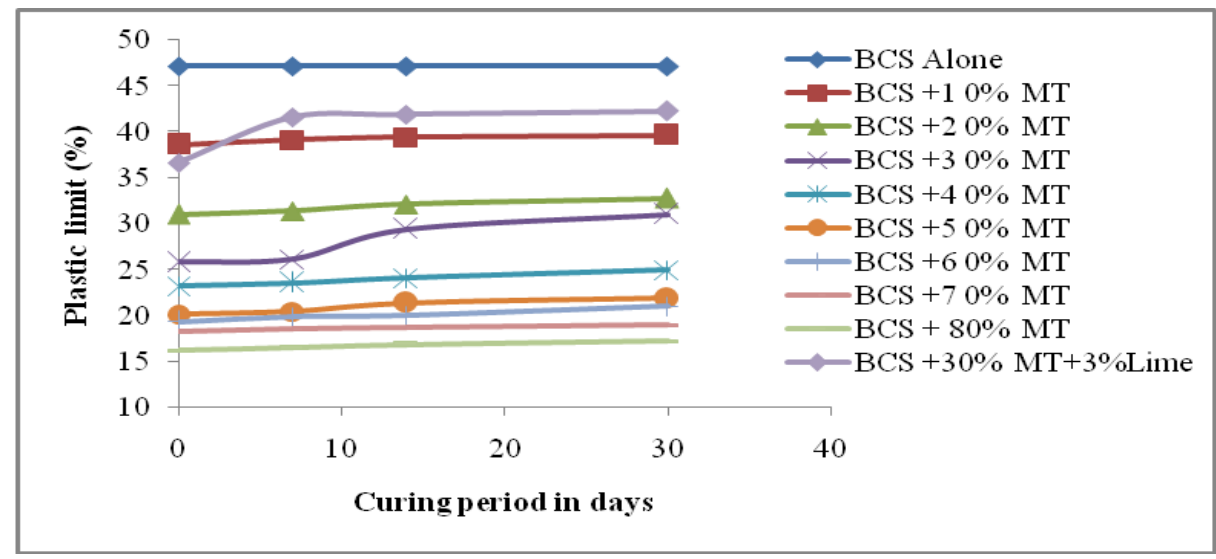

Fig. 2 Variation of plastic limit of black cotton soil treated with various percentages of mine tailings and lime for different curing periods

\subsection{Effect of lime on the shrinkage limit of black cotton soil and mine tailings mixture}

The shrinkage limit is extremely useful parameter in the areas where soils undergo large volume changes due to wet and dry cycles. It was observed that the shrinkage limit of black cotton soil and mine tailings are $8.2 \%$ and $26.6 \%$ respectively. Addition of various percentages of mine tailings to black cotton soil the shrinkage limit increases with increase in curing period. Addition of optimum 3\% of lime to black cotton soil and mine tailings mixture, the shrinkage limit is found to be $21.7 \%$ at immediate testing and further it increases to $32.6 \%$ for 30 days of curing as shown in Fig. 3 and Table 6. The shrinkage limit of black cotton soil and mine tailings mixtures progressively increases with lime addition on immediate testing and exhibits 
significant increase with increase in curing period. The instantaneous increase in shrinkage limit is attributed to flocculation brought about by cation exchange and particle agglomeration reactions with curing period. (Prakash et al 1989)[20]. The shrinkage limit of black cotton soil and mine tailings mixture increased immediately on lime treatment due to flocculation of clay particles. However, with curing time shrinkage limit increases. This indicate that the flocculation of clay particles improved immediately and for curing period on the addition of lime (Sivapullaiah et al 1995)[21].

Table 6. Shrinkage limit of black cotton soil treated with various percentages of mine tailings and lime for different curing periods

\begin{tabular}{|l|c|c|c|c|}
\hline \multirow{2}{*}{ Mixtures } & \multicolumn{4}{|c|}{ Shrinkage Limit (\%) } \\
\cline { 2 - 5 } & \multicolumn{4}{|c|}{ Curing period in days } \\
\hline & 0 & 7 & 14 & 30 \\
\hline BCS Alone & 8.4 & 8.4 & 8.4 & 8.4 \\
\hline MT Alone & 24.6 & 26.72 & 26.8 & 27.1 \\
\hline BCS +1 0\% MT & 8.87 & 9.26 & 10.8 & 11.2 \\
\hline BCS +2 0\% MT & 9.24 & 10.58 & 11 & 12 \\
\hline BCS +3 0\% MT & 9.58 & 11.6 & 12.2 & 13.5 \\
\hline BCS +4 0\% MT & 10 & 12.2 & 13.4 & 16.5 \\
\hline BCS +5 0\% MT & 11.1 & 14.8 & 16.2 & 19.9 \\
\hline BCS +6 0\% MT & 17.9 & 18.5 & 20.5 & 22.8 \\
\hline BCS +7 0\% MT & 19.6 & 20.1 & 21.5 & 25.4 \\
\hline BCS + 80\% MT & 20.1 & 23.9 & 25.7 & 32.2 \\
\hline BCS + 90\% MT & 22 & 25.1 & 31.2 & 37.1 \\
\hline BCS +30\% MT+3\%Lime & 21.7 & 24.6 & 27.5 & 32.6 \\
\hline
\end{tabular}

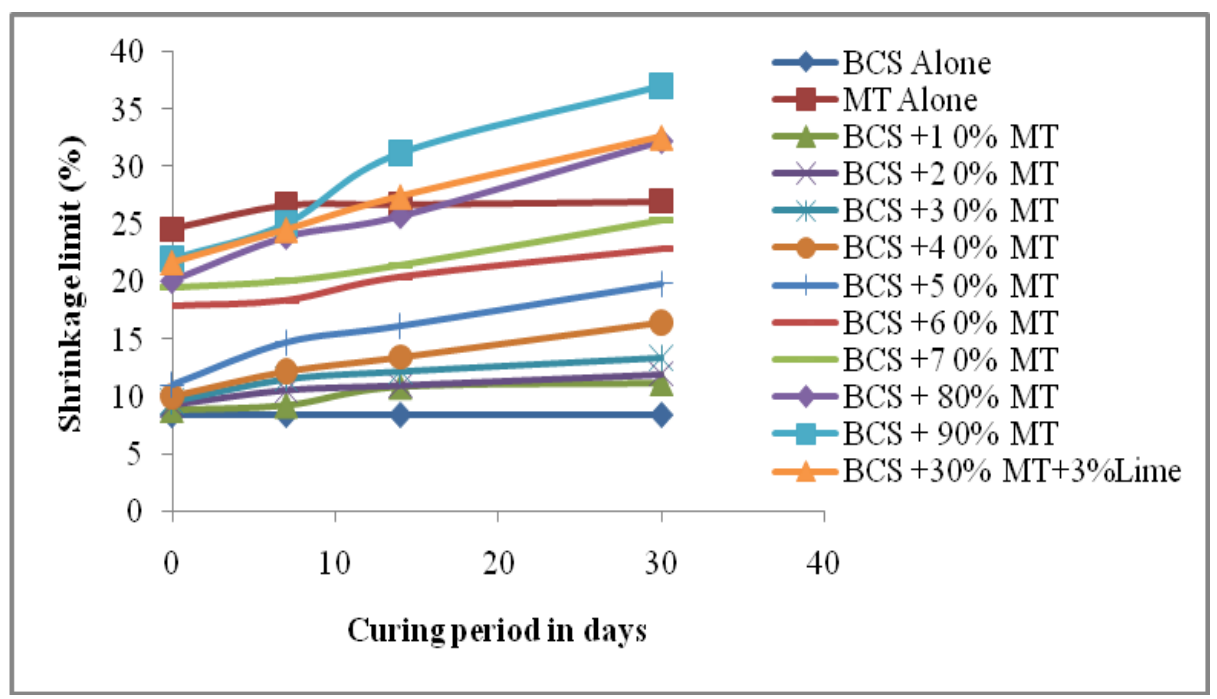

Fig. 3 Variation of shrinkage limit of black cotton soil treated with various percentages of mine tailings and lime for different curing periods

\subsection{Effect of lime on the plasticity index of black cotton soil and mine tailings mixture:}

Plasticity index is one of the important criteria for selection of soil as construction material. Generally, reduction in plasticity index is desirable as it increases the workability. Plasticity index of black cotton soil is $34.8 \%$ the untreated black cotton soil can be classified using casagrande classification chart which is on the border line between silt and clay of medium compressibility. Plasticity index of black cotton soil reduces with increase in mine tailings proportions, black cotton soil changes its classification to CI (sandy and silty clay having medium plasticity with medium compressibility) when treated with mine tailings in the range of 50 to $80 \%$ as shown in Fig. 4. Plasticity index reduces from $34.8 \%$ to $29.7 \%$ when black cotton soil treated with optimum percentages of mine tailings and lime. It indicate that there is slight variation in plasticity index which lies below the A-line having high compressible material. Plasticity index of black cotton soil and mine tailings mixture treated with lime reduced to $17 \%$ compared to untreated black cotton soil after 30 days of curing. The reduction in plasticity indices are indication for soil improvement (Amu et al 2011). 


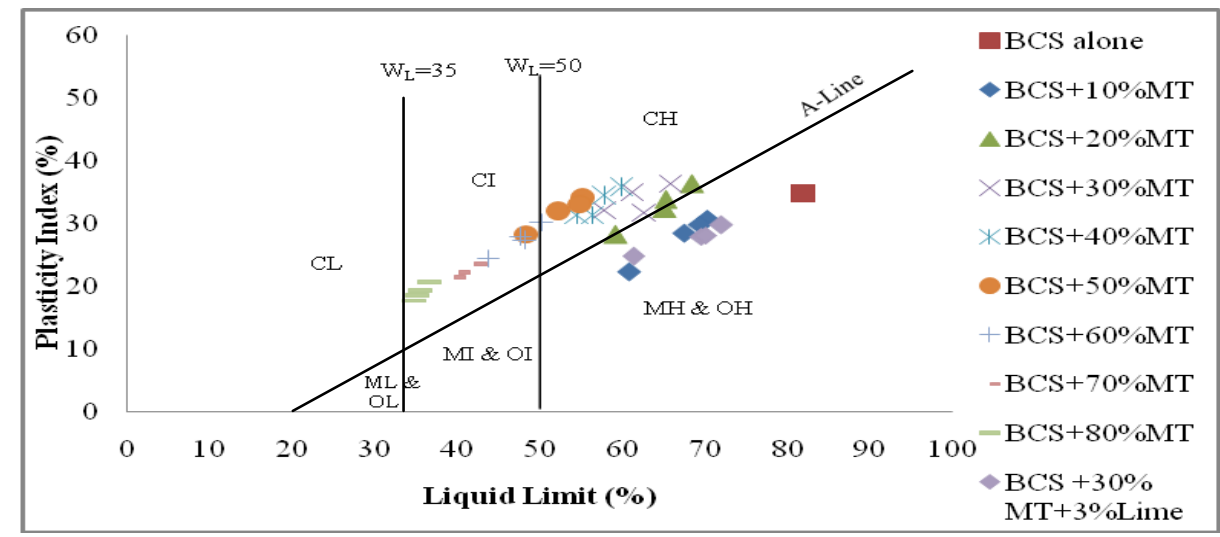

Fig. 4 Classification of lime treated black cotton soil in presence of mine tailings with curing

\section{CONCLUSIONS}

From the present investigation the effect of lime on the index properties of black cotton soil and mine tailings mixture treated with lime, the following conclusions are drawn

- Liquid limit of black cotton soil and mine tailings mixtures decreases for all the curing periods due to depression in the diffused double layer thickness associated with the clay particles and it increases with increase in curing period for black cotton soil and mine tailings mixture treated with lime due to prolonged equilibrium of the soil-lime-mine tailings mixture resulted in formation of coarser particles and more flocculated particle arrangement.

- Plastic limit of black cotton soil and mine tailings mixtures decreases for all the curing periods and it increases with increase in curing period for black cotton soil and mine tailings mixture treated with lime due to decrease in the diffused double layer thickness of clay particles leads to increase in the shearing resistance at particle level and also flocculation of clay particles which leads to increase in plastic limit with curing periods.

- Shrinkage limit of black cotton soil and mine tailings mixtures increases for all the curing period and the same trend has been observed for black cotton soil and mine tailings mixture treated with lime, the increase in shrinkage limit is attributed to flocculation brought about by cation exchange and particle agglomeration reactions with curing period.

- Plasticity index of black cotton soil and mine tailing mixture treated with lime reduces compare to untreated black cotton soil after 30 days of curing, the reduction in plasticity index is the indication of improvement of properties of soil with the addition of lime and mine tailings.

\section{REFERENCES}

[1] G.F.Sowere, A.Vesic and M.Grandolfi, "Penetration tests for liquid limit", Procedings of a Symposium on Atterberg Limits., ASTM No. STP 254, PP.216-224

[2] F.G.Bell, "Stabilization and Treatment of Clay Soil with Lime-Part 1-Basic Principles", Ground Engineering, Vol.21, No.1, pp. 10-15., 1988a

[3] F.G.Bell, "Stabilization and Treatment of Clay Soil with Lime-Part 2-Some Applications", Ground Engineering, Vol.21, No.2, pp. 25-29., 1988b

[4] S.Diamond and E.B.Kinter, "Mechanisms of Lime Stabilization", Highway Research Record, 92, p.83., 1965

[5] M.R.Thompson, "Lime Reactivity of Illinois soils", Jour. S.M.F.Div. ASCE., Vol.92, S.M.S, pp 67-92., 1966

[6] Pebble Project, "Tailings and Tailings Managements", Northern Dynasty Mines Inc, pp 1-4., 2005

[7] A.Sridharan, S.M.Rao and N.S.Murthy, "Liquid limit of Montmorillonite Soils", ASTM Geotechnical Testing Journal, Vol.9, No.3 pp.156-159., 1982

[8] R.K.Katti, Kulkarni and N. Radhakrishna, "Research on Black Cotton Soils without and with inorganic additives, " Road Research Bullition, No.10, The Indian Road congress., 1966

[9] C.P. Worth, "Correlation of some engineering properties of soils", 2nd International Conference on Boss, Imperial College, Londen, 121-132., 1979

[10] A.Sridharan and M.S.Jayadeva, "Double layer theory and compressibility of clays", Geotechnique, Vol. 32, pp.133-144., 1982

[11] Udayashankar.D.Hakari and S.C.Puranik, "Stabilization of Black Cotton Soils using Fly Ash, HubballiDharwad Municipal Corporation Area, Karnataka, India" Global Journal of Researches in Engineering Civil \& Structural Engineering, Vol.12, pp 21-28., 2012 
[12] P.R.Hesse, "A Text Book of Soil Chemical Analysis" Published by Chemical Pub. Co., University of Michign., 1972

[13] Ramesh H.N, Krishnaiah A.J and Venugopala S.R, "Compaction and Strength Behaviour of Black cotton soil Treated with Mine tailings", Procedings of Indian Geotechnical Conference (IGC), Vol.2.pp838841., 2012

[14] IS: 2720 (Part V)-Indian Standard Methods of tests for soils: Determination of Liquid limit., 1985

[15] IS: 2720 (Part V)-Indian Standard Methods of tests for soils: Determination of Plastic limit., 1985

[16] IS: 2720 (Part V)-Indian Standard Methods of tests for soils: Determination of Shrinkage limit., 1972

[17] Ramesh H.N, Krishnaiah A.J, Compaction and strength behaviour of black cotton soil and mine tailings mixtures treated with lime and sodium salts, International Journal of Geotechnical Engineering, (ASCE)., Communicated 2013

[18] P.T.Sherwood, "Effect of Sulphates on Cement and Lime Treated Soils", Highway Research Board Bullition, No.353, PP 98-107., 1958

[19] W.H Taylor and A.Arman, "Lime stabilization using precondition soils", Highway Research Board Bullition, No.266, pp.1-19

[20] K.Prakash, A.Sridharan and S.M.Rao, "Lime addition and curing effects on the Index and Compaction Characteristics of a Montmorillonite Soils", Geotechnical Engineering, Vol.20, pp.39-47

[21] P.V.Sivapullaiah, A.Sridharan and H.N.Ramesh, "Mechanisms Controlling the Index Properties of Lime Treated Black Cotton Soil in the Presence of Sulphate", Indian Geotechnical Journal, Vol.25 (3), pp.379394., 1995 